\title{
Penentuan Lokasi Kawasan Industri Tekstil Terpadu di Kabupaten Majalengka
}

\author{
Irwan Bisri Rianto dan Eko Budi Santoso \\ Perencanaan Wilayah dan Kota, Fakultas Arsitektur Desain dan Perencanaan \\ Institut Teknologi Sepuluh Nopember (ITS) \\ e-mail: eko_budi@urplan.its.ac.id
}

\begin{abstract}
Abstrak-Kabupaten Majalengka merupakan salah satu Kabupaten di Jawa Barat yang direncanakan sebagai pengembangan kawasan industri tekstil Jawa Barat. Kecamatan Ligung dan Kecamatan Jatitujuh merupakan kawasan peruntukan industri terutama sebagai pengembangan industri tekstil. Kabupaten Majalengka sebagai bagian dari wilayah pengembangan kawasan Ciayumajakuning memiliki arahan dari Departemen Perindustrian Republik Indonesia untuk merelokasi kawasan industri tekstil dan produk tekstil dari Bandung Selatan ke Kabupaten Majalengka. Hal ini disebabkan sektor industri di Kabupaten Bandung Selatan mengalami kejenuhan. Penelitian ini menggunakan teori lokasi dan pengembangan kawasan industri dengan menggunakan analisis Delphi untuk mengindentifikasi variabel-variabel yang berpengaruh terhadap penentuan lokasi kawasan industri tekstil menurut preferensi stakeholder, analsisis $A H P$ untuk menentukan tingkat kepentingan dari variabel variabel, dan analisis GIS Overlay untuk menentukan lokasi kawasan industri tekstil terpadu. Dari hasil penelitian terdapat lima indikator yang berpengaruh terhadap penentuan lokasi kawasan industri tekstil terpadu yaitu tapak/lahan, risiko bencana, utilitas, aksesibilitas, dan prinsip pengembangan kawasan. Dari hasil analisis overlay didapatkan hasil berupa peta lokasi terpilih yang dapat digunakan sebagai lokasi kawasan industri tekstil terpadu. Tingkat kesesuaian kawasan industri paling tinggi berada rentang 0.8924-1. Dari hasil analisis diperoleh bahwa lahan yang sesuai untuk dijadikan kawasan industri tekstil terpadu seluas 2.325 Ha tersebar di Kecamatan Jatitujuh dan Ligung dengan luas per kawasan yaitu 54,9 ha hingga 319,6 ha.
\end{abstract}

Kata Kunci-Penentuan Lokasi, Kawasan Industri Tekstil Terpadu, Delphi, AHP, GIS Overlay.

\section{PENDAHULUAN}

$\mathrm{P}$ ENGEMBANGAN kawasan industri tekstil di Jawa Barat telah direncanakan di Kabupaten Majalengka. Rencana pengembangan komponen industri tekstil yang akan dikembangkan adalah industri pembuatan benang polyester dan benang rayon yang akan dikembangkan di Kabupaten Majalengka, selain itu untuk komponen industri yang lain seperti benang nylon, pintal, dan sutera perlu dibangun juga di lokasi industri prioritas tekstil salah satunya di Kabupaten Majalengka [1].

Di Jawa Barat, industri tekstil merupakan salah satu subsektor yang memiliki peranan besar di sektor industri dengan kontribusi sebesar 14,9\% pada tahun 2016. Hal ini juga terlihat peranan industri tekstil yang besar jika dilihat dari distribusi seluruh sub sektor yaitu sebesar 6,36\% pada tahun yang sama. Pada tahun 2014 realisasi investasi dalam negeri, sub sektor industri tekstil memiliki jumlah sebesar 2,92 triliun rupiah atau $45,93 \%$ terhadap sub sektor industri lainnya. Untuk realisasi investasi luar negeri sub sektor industri tekstil memiliki jumlah sebesar 2,714 triliun rupiah atau 5,03\% terhadap sub sektor industri lainnya pada tahun yang sama [2].

Kontribusi sektor industri di Majalengka terhadap PDRB Kabupaten Majalengka berada di posisi ke tiga di bawah perdagangan dan pertanian yaitu sebesar $14 \%$ terhadap sektor lainnya. Kontribusi sektor industri dengan nilai PDRB atas dasar harga berlaku sebesar 2.906 triliun rupiah $(13,68 \%)$ pada tahun 2015, meningkat menjadi 3.309 triliun rupiah $(14,31 \%)$ pada tahun 2016. Sedangkan berdasarkan harga konstan, nilai PDRB sektor industri 1.744 triliun rupiah $(13,5 \%)$ pada tahun 2015, meningkat menjadi 1.825 triliun rupiah $(13,54 \%)$ pada tahun 2016 [3].

Wilayah peruntukan industri sudah ditetapkan di Kabupaten Majalengka ada di Kecamatan Jatitujuh, Kecamatan Kadipaten, Kecamatan Kertajati, Kecamatan Ligung, Kecamatan Dawuan, Kecamatan Kasokandel, Kecamatan Jatiwangi, Kecamatan Sumberjaya, Kecamatan Leuwimunding, dan Kecamatan Palasah. Wilayah tersebut diperuntukkan untuk industri besar dan menengah, sedangkan peruntukan industri tekstil diarahkan ke Kecamatan Jatitujuh dan Ligung. Kabupaten Majalengka sebagai bagian dari wilayah pengembangan Ciayumajakuning memiliki arahan dari Departemen Perindustrian Republik Indonesia untuk merelokasi kawasan industri tekstil dan produk tekstil dari Bandung Selatan ke Kabupaten Majalengka. Hal ini disebabkan wilayah untuk sektor industri mengalami kejenuhan. Relokasi industri tekstil ke Kabupaten Majalengka merupakan salah satu isu regional Jawa Barat. Permasalahan yang ada saat ini pemerintah Kabupaten Majalengka belum memiliki kawasan yang disediakan untuk dijadikan kawasan industri tekstil. Selain itu, Kabupaten Majalengka perlu pemusatan kawasan industri tekstil terpadu di wilayah peruntukan industri tekstil, sehingga terbentuk aglomerasi industri [4].

Dalam menetapkan suatu lokasi kegiatan industri tidak bisa ditetapkan oleh sebuah teori tunggal. Penetapan lokasi industri terutama skala besar dibutuhkan gabungan dari berbagai teori pendukung. Salah satu faktor pemilihan lokasi dikemukakan Assauri adalah faktor lahan dengan mempertimbangkan kemiringan lahan, jenis tanah, penggunaan lahan, harga lahan dan utilitas dengan mempertimbangkan jaringan listrik dan jaringan air bersih. Djojodipuro dalam Kumalasari (2012) [5] 
juga mengungkapkan beberapa faktor yang mempengaruhi pemilihan lokasi industri diantaranya faktor lahan. Kondisi topografi tanah karena hal ini akan berpengaruh terhadap konsekuensi biaya pembangunan industri, ketersediaan tanah yang luas untuk pengembangan kantor dan lahan parkir, dan harga lahan yang murah akan menjadi daya tarik tersendiri bagi pengusaha industri. Selain itu jaringan jalan, faktor lahan, utilitas dengan memperhatikan jaringan listrik dan air, dan aglomerasi menjadi faktor lainnya dalam pemilihan lokasi industri [5].

Pendapat lainnya seperti Sigit berpendapat lingkungan mempengaruhi dalam menentukan lokasi industri. Pengaruh lingkungan dimaksud adalah kebencanaan seperti banjir, tanah longsor, atau jenis bencana lainnya. Selain itu kegiatan industri juga akan mempengaruhi lingkungan sekitar sehingga perlu ada kajian lingkungan dalam menentukan lokasi industri [6].

Dalam rantai nilai industri industri tekstil menghasilkan hasil produksi yang berbeda-beda seperti benang, kain, dan pakaian. Konsep ini dikemukakan oleh Sturgeon, konsep rantai nilai akan menghasilkan nilai tambah dari hasil produksi. Hal ini merupakan sebuah bagian terstruktur yang saling membutuhkan setiap jenis industri tekstil. Untuk pembangunan industri tekstil, Sorensen memperhatikan regulasi yang ada di wilayah yang akan dibangun. Di Indonesia regulasi mengacu pada RTRW dan peraturan lain yang mengatur industri tekstil. Industri tekstil (terutama industri menengah dan besar) tidak bisa membangun di luar wilayah peruntukkannya, sehingga peraturan penataan ruang perlu ditaati dan sesuai dengan rencana tata ruangnya [7].

Pedoman teknis kawasan industri diperlukan sebagai acuan dalam pembangunan dan pengembangan kawasan industri. Acuan atau pedoman ini diperuntukkan bagi aparatur pemerintah daerah, dunia usaha, dan pihak-pihak berkepentingan dalam melaksanakan pembinaan dan pengembangan kawasan industri. Kriteria pemilihan lokasi kawasan industri dari Permerind no. 30 tahun 2010 memperhatikan kemiringan lereng, jaringan jalan,jaringan listrik, jaringan air bersih, jaringan drainase, kerawanan bencana longsor, harga lahan, penggunaan lahan dan jenis tanah [8].

\section{METODE PENELITIAN}

\section{A. Jenis dan Pendekatan Penelitian}

Pendekatan yang digunakan dalam penelitian ini adalah pendekatan eksploratif dan rasionalisme. Jenis penelitian dalam penelitian ini adalah eksploratif [9].

\section{B. Variabel Penelitian}

Variabel penelitian yang digunakan untuk menentukan lokasi kawasan industri tekstil terpadu di Kabupaten Majalengka antara lain kemiringan lahan/topografi, jenis tanah, penggunaan lahan, harga lahan, bencana gempa bumi, bencana banjir, bencana longsor, jaringan listrik, jaringan air bersih, jaringan drainase, jaringan jalan, lebar jalan, perkerasan jalan, kesesuaian dengan rencana tata ruang dan rantai nilai industri.
C. Identifikasi Variabel yang Berpengaruh Dalam Penentuan Lokasi Kawasan Industri Tekstil Terpadu menggunakan Analisis Delphi

Analisis ini diperlukan pakar yang memiliki relevansi terhadap penelitian. Dari pakar tersebut akan dijadikan narasumber untuk melakukan konfirmasi variabel yang berpengaruh dalam penentuan lokasi kawasan industri tekstil. Analisis ini dapat dikatakan berhasil jika semua pendapat dari narasumber telah mencapai konsensus. Apabila pendapat dari narasumber belum mencapai konsensus maka diperlukan iterasi (pengurangan) hingga tercapai konsensus. Untuk memulai analisis ini diperlukan penentuan sampel dengan menggunakan purposive sampling. Purposive sampling dilakukan untuk mendapatkan responden yang benar-benar memiliki pemahaman tentang penentuan lokasi industri tekstil. Setelah penentuan responden, langkah berikutnya adalah analisis delphi. Analisis delphi digunakan untuk memperoleh konsensus grup atau expert yang dilakukan secara kontinu sehingga diperoleh konvergensi opini [9]. Tahapan analisis delphi yang dilakukan dalam penelitian ini:

1. Spesifikasi permasalahan

Perumusan isu permasalahan yang diangkat untuk dikomentari oleh responden.

2. Merumuskan kuisioner I

Merumuskan item-item mana yang akan diajukan dalam kuisioner berupa daftar pertanyaan untuk dipakai pada putaran pertama dan selanjutnya.

3. Wawancara Delphi Putaran I

Pada tahap ini dilakukan proses wawancara terhadap responden yang dipilih melalui purposive sampling. Tahap ini peneliti berprinsip pada anonimitas delphi, di mana semua responnden memberikan tanggapan secara terpisah dan tidak mengetahui siapa responden yang lain.

4. Analisis Hasil Putaran I

Pada tahap ini, langkah-langkah yang dilakukan adalah:

- Mengumpulkan dan memverifikasi hasil pendapat responden

- Mengintepretasi kecenderungan pendapat responden

- Mengeliminasi pertanyaan-pertanyaan yang tidak diperlukan lagi untuk putaran selanjutnya

- Menyusun pertanyaan untuk kuisioner selanjutnya dan mewawancarai hasil analisis putaran I kepada responden.

5. Pengembangan Kuisioner Selanjutnya

Pada pelaksanaannya teknik ini dapat berlangsung lebih dari sekali putaran. Langkah selanjutnya yang akan dilakukan setelah putaran pertama adalah menyusun kuisioner yang berisi pertanyaan untuk putaran berikutnya dengan hasil putaran sebelumnya dijadikan basis untuk putaran selanjutnya. Pada tahap analisis ini akan diperoleh konsensus dari responden mengenai variabel apa saja yang berpengaruh terhadap kriteria lokasi kawasan industri tekstil. 
D. Analisis Tingkat Kepentingan Variabel Penentu Lokasi Kawasan Industri Tekstil Terpadu di Kabupaten Majalengka

Pada tahap analisis ini variabel yang berpengaruh terhadap penentuan lokasi kawasan industri tekstil di Kabupaten Majalengka telah diketahui. Sebelum digunakan untuk tahap analisis selanjutnya penting dilakukan analisis pembobotan agar diketahui variabel-variabel prioritas di Kabupaten Majalengka. Alat analisis yang digunakan pada tahap ini adalah dengan menggunakan analisis AHP. Untuk menggunakan analisis ini diperlukan wawancara terhadap seorang expert atau orang yang ahli pada bidang yang diteliti [10]. Berikut adalah tahapan analisis:

1. Penyusunan hierarki

2. Kuisioner

3. Pengolahan dengan matriks berpasangan (pairwise comparison)

4. Perbandingan untuk memperoleh prioritas (Uji Normalisasi)

5. Uji konsistensi

6. Penggabungan pendapat responden

E. Analisis Penentuan Lokasi Kawasan Industri Tekstil di Kabupaten Majalengka

Pada tahap ini, analisis yang digunakan untuk mencari lokasi yang sesuai untuk menentukan kawasan industri tekstil. Pada penentuan lokasi ini digunakan variabel yang sudah didapat dari tahap analisis sebelumnya. Dari variabel dan bobot yang akan digunakan, peta-peta tersebut akan dilakukan analisis overlay dengan bobot yang sudah ditentukan pada analisis AHP.

Sebelum melakukan overlay dilakukan binary scoring untuk proses reclassify yang merupakan proses justifikasi nilai untuk penyeragaman format pada penilaian variabel. Data yang dimasukkan untuk melakukan analisis ini harus dalam bentuk raster. Pada data polyline atau point dilakukan proses euclidean distance untuk melakukan buffering. Hal ini dilakukan agar mendapatkan luasan yang sesuai untuk dilakukan proses overlay [11].

Tahapan operasional dari analisis weighted overlay adalah:

1. Add rasters; memasukkan data yang akan dioverlay

2. Select field; pemilihan field input yang akan dioverlay

3. Assign weights for input rasters; pemberian bobot pada data input

4. Run the weighted overlay tool; evaluasi untuk mendapatkan output overlay.

\section{HASIL DAN DISKUSI}

A. Identifikasi Variabel yang Berpengaruh Dalam Penentuan Lokasi Kawasan Industri Terpadu di Kabupaten Majalengka

Pada tahap ini dilakukan analisis Delphi untuk menentukan variabel yang berpengaruh dan digunakan sebagai penentu lokasi kawasan industri tekstil terpadu. Responden yang dimimntai pendapatnya pada penelitian ini adalah Bappelitbangda Kabupaten Majalengka, Dinas BMCK Majalengka, Dinas LH Majalengka, Pelaku industri tekstil, dan Tenaga konsultan.
Wawancara ini dilakukan melalui dua kali putaran untuk mendapatkan variabel yang terkonsesnsu. Setelah dilakukan iterasi 15 variabel telah mencapai konsensus. Keseluruhan variabel digunakan untuk analisis selanjutnya yaitu menentukan tingkat kepentingan dari masing-masing variabel. Berikut ini adalah indikator dan variabel yang telah terkonsensus:

1. Indikator Tapak/Lahan dengan variabel kemiringan lahan/ topografi, jenis tanah, penggunaan lahan, dan harga lahan.

2. Indikator Risiko Bencana dengan variabel bencana gempa bumi, bencana banjir, dan bencana longsor.

3. Indikator Utilitas dengan variabel jaringan listrik, air bersih, dan drainase.

4. Indikator Aksesibilitas denan variabel jaringan jalan, lebar jalan, dan perkerasan jalan.

5. Indikator Prinsip Pengembangan Kawasan dengan variabel kesesuaian dengan rencana tata ruang dan rantai nilai industri tekstil.

\section{B. Analisis Tingkat Kepentingan Variabel Penentu Lokasi} Kawasan Industri Tekstil Terpadu di Kabupaten Majalengka

Dalam analisis tingkat kepentingan variabel penentu lokasi kawasan industri tekstil terpadu di Kabupaten Majalengka menggunakan analisis $A H P$. Analisis $A H P$ ini menggunakan bantuan Expert Choice 11. Berikut ini adalah hasil kombinasi seluruh stakeholder dari masing-masing indikator penentuan lokasi kawasan industri tekstil:

Tabel 2

Rekapitulasi Masing-Masing Bobot Dari Indikator Dan Variabel Dari Hasil Kombinasi Stakeholder

\begin{tabular}{|c|c|c|c|}
\hline Indikator & Nilai & Variabel & Nilai \\
\hline \multirow[t]{4}{*}{ Tapak/Lahan } & \multirow[t]{4}{*}{0,285} & $\begin{array}{l}\text { Kemiringan Lahan/ } \\
\text { Topografi }\end{array}$ & 0,118 \\
\hline & & Jenis Tanah & 0,105 \\
\hline & & Penggunaan Lahan & 0,515 \\
\hline & & Harga Lahan & 0,262 \\
\hline \multirow[t]{3}{*}{ Risiko Bencana } & \multirow[t]{3}{*}{0,210} & Bencana Gempa Bumi & 0,348 \\
\hline & & Bencana Banjir & 0,303 \\
\hline & & Bencana Longsor & 0,348 \\
\hline \multirow[t]{3}{*}{ Utilitas } & \multirow[t]{2}{*}{0,164} & Jaringan Listrik & 0,254 \\
\hline & & Jaringan Air Bersih & 0,503 \\
\hline & & Jaringan Drainase & 0,243 \\
\hline \multirow[t]{3}{*}{ Aksesibilitas } & \multirow[t]{3}{*}{0,129} & Jaringan Jalan & 0,487 \\
\hline & & Lebar Jalan & 0,281 \\
\hline & & Perkerasan Jalan & 0,232 \\
\hline \multirow{2}{*}{$\begin{array}{l}\text { Prinsip } \\
\text { Pengembangan } \\
\text { Kawasan }\end{array}$} & \multirow[t]{2}{*}{0,212} & $\begin{array}{l}\text { Kesesuaian dengan } \\
\text { Rencana Tata Ruang }\end{array}$ & 0,535 \\
\hline & & Rantai Nilai Industri & 0,465 \\
\hline
\end{tabular}

Hasil proses kombinasi seluruh stakeholders analisis tingkat kepentingan dari masing-masing indikator penentuan lokasi kawasan industri tekstil dihitung dengan aplikasi expert choice 11. Tingkat kepentingan dari indikator penentuan lokasi kawasan industri tekstil di Kabupaten Majalengka menunjukkan hasil analisis AHP bahwa nilai dari indikator dalam penentuan kawasan industri tekstil terpadu adalah tapak/ lahan $(0,285)$, prinsip pengembangan kawasan $(0,212)$, risiko bencana $(0,210)$, utilitas $(0.164)$, dan aksesibilitas $(0,129)$. Nilai inkonsistensi sebesar 0,00579 . 


\section{Analisis Penentuan Lokasi Kawasan Industri Tekstil di Kabupaten Majalengka}

Pada tahap ini adalah analisis terakhir pada penelitian ini. Pada tahap ini akan digunakan teknik analisis overlay. Pada analisis ini akan seluruh peta harus pada format raster sehingga dapat digabungkan peta-peta tematis tersebut berdasarkan variabel-variabel yang sudah ditentukan. Sebelum melakukan proses overlay ada satu tahap lain yaitu proses reclassify yang merupakan proses justifikasi nilai untuk penyeragaman format pada penilaian variabel. Pada proses overlay dengan menggunakan metode weighted overlay dengan digunakan bobot untuk tiap variabel. Bobot untuk tiap variabel merupakan hasil analisa AHP. Bobot untuk masing-masing variabel dapat dilihat pada tabel dibawah ini :

Tabel 3

Bobot Nilai Tiap Peta Variabe

\begin{tabular}{|l|c|}
\hline \multicolumn{1}{|c|}{ Peta Dasar } & Bobot \\
\hline \multicolumn{1}{|c|}{ Variabel Lahan } \\
\hline Peta Kemiringan Lahan/Topografi & 0.04 \\
\hline Peta Jenis Tanah & 0.03 \\
\hline Peta Penggunaan Lahan & 0.15 \\
\hline Peta Harga Lahan & 0.08 \\
\hline \multicolumn{2}{|c|}{ Variabel Risiko Bencana } \\
\hline Peta Bencana Gempa Bumi Utilitas & 0.07 \\
\hline Peta Bencana Banjir & 0.06 \\
\hline Peta Bencana Longsor Variabel Aksesibilitas \\
\hline \multicolumn{2}{|c|}{0.07} \\
\hline Peta Jaringan Listrik & 0.04 \\
\hline Peta Jaringan Air Bersih & 0.08 \\
\hline Peta Jaringan Drainase & 0.04 \\
\hline \multicolumn{2}{|c|}{ Variabel Prinsip Pengembangan Kawasan } \\
\hline Peta Jaringan Jalan & 0.06 \\
\hline Peta Lebar Jalan & 0.04 \\
\hline Peta Perkerasan Jalan & 0.11 \\
\hline \multicolumn{2}{|c|}{ Peta Kesesuaian dengan Rencana Tata Ruang } \\
\hline Peta Rantai Nilai Industri & 1.00 \\
\hline Jumlah
\end{tabular}

Pada proses overlay, peta yang digunakan sudah pada format raster dengan telah melalui justifikasi pada tahap sebelumnya untuk melakukan tahap overlay ini. Pada tahap ini dibantu dengan software ArcGIS 10.1. Berikut ini adalah peta hasil overlay kawasan industri tekstil terpadu.

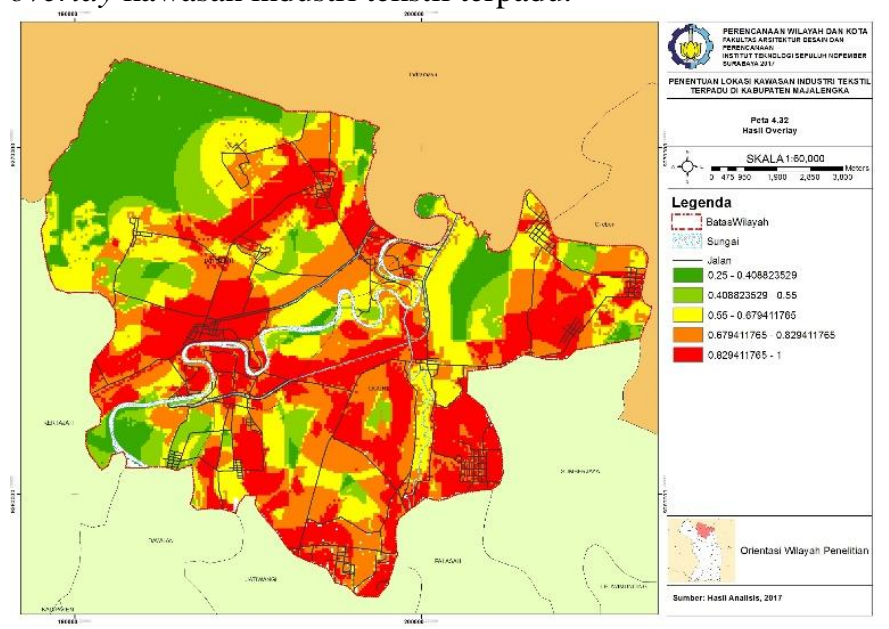

Gambar 1. Peta hasil Overlay
Warna merah pada peta diatas menggambarkan kesesuian lahan paling tinggi, sedangkan warna hijau menggambarkan nilai yang rendah. Untuk pemilihan lokasi kawasan industri tekstil terpadu dilakukan reduksi, dimana luas lahan $\geq 50$ ha dipilih sebagai kawasan kawasan industri tekstil terpadu. Berikut ini adalah lokasi terpilih sebaga kawasan industri tekstil terpadu.

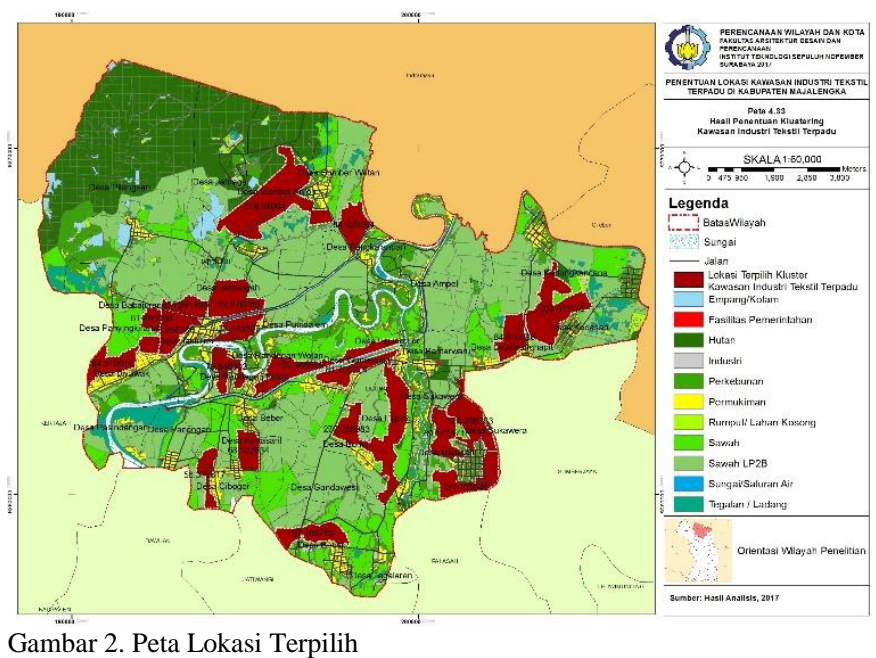

Warna merah tua pada peta di atas menunjukkan lokasi terpilih sebagai kawasan industri tekstil terpadu. Dari hasil analisis diperoleh bahwa lahan yang sesuai untuk dijadikan kawasan industri tekstil terpadu seluas $2.325 \mathrm{Ha}$ tersebar di Kecamatan Jatitujuh dan Ligung dengan luas per kawasan yaitu 54,9 ha hingga 319,6 ha. Desa yang tercakup kawasan kawasan industri tekstil terpadu di Kecamatan Jatitujuh adalah Desa Jatiraga, Sumber Kulon, Desa Sumber Wetan, Desa Pangkalanpari, Desa Jatitengah, Desa Biyawak, Desa Babajurang, dan Desa Jatitujuh. Desa yang tercakup kawasan kawasan industri tekstil terpadu di Kecamatan Ligung adalah Desa Beusi, Cibogor, Kertasari, Buntu, Ligung, Sukawera, Majasari, Leuweunghapit, Kodasari, Kedungkencana, Ligung Lor, Wanasalam, Randegan Wetan, dan Randegan Kulon.

\section{KESIMPULAN}

Pada penelitian ini bertujuan untuk menentukan lokasi kawasan industri tekstil terpadu di Kabupaten Majalengka. Berikut ini merupakan hasil yang diperoleh dari penelitian ini :

1. Berdasarkan hasil analisis delphi, untuk menentukan lokasi kawasan industri tekstil di Kabupaten Majalengka perlu mempperhatikan faktor tapak/ lahan, risiko bencana, utilitas, aksesibilitas, dan prinsip pengembangan kawasan. Selain itu dalam faktor tapak/ lahan perlu memperhatikan variabel kemiringan lahan, jenis tanah, penggunaan lahan, dan harga lahan. Dalam faktor risiko bencana perlu memperhatikan kerawanan bencana gempa bumi, bencana banjir, dan bencana longsor. Dalam faktor utilitas perlu memperhatikan variabel jaringan listrik, air bersih, dan drainase. Dalam faktor aksesibilitas perlu memperhatikan variabel jaringan jalan, lebar jalan, dan perkerasn jalan. Dalam faktor prinsip pengembangan kawasan perlu 
memperhatikan variabel kesesuaian dengan rencana tata ruang dan rantai nilai industri tekstil.

2. Setelah melakukan proses analisis dengan mengggunakan AHP dibantu dengan software expert choice 11 diketahui bahwa di antara keseluruhan indikator yang didapat, tapak/ lahan 0,285 mempunyai tingkat kepentingan paling tinggi, prinsip pengembangan kawasan 0,212 , risiko bencana 0,210 , utilitas 0.164, dan aksesibilitas 0,129.

3. Berdasarkan hasil analisis overlay didapatkan hasil berupa peta lokasi terpilih yang dapat digunakan sebagai lokasi kawasan industri tekstil terpadu. Tingkat kesesuaian kawasan industri paling tinggi berada rentang 0.8924-1. Dari hasil analisis diperoleh bahwa lahan yang sesuai untuk dijadikan kawasan industri tekstil terpadu seluas 2.325 Ha tersebar di Kecamatan Jatitujuh dan Ligung dengan luas per kawasan yaitu 54,9 ha hingga 319,6 ha. Desa yang tercakup kawasan kawasan industri tekstil terpadu di Kecamatan Jatitujuh adalah Desa Jatiraga, Sumber Kulon, Desa Sumber Wetan, Desa Pangkalanpari, Desa Jatitengah, Desa Biyawak, Desa Babajurang, dan Desa Jatitujuh. Desa yang tercakup kawasan kawasan industri tekstil terpadu di Kecamatan Ligung adalah Desa Beusi, Cibogor, Kertasari, Buntu, Ligung, Sukawera, Majasari, Leuweunghapit, Kodasari, Kedungkencana, Ligung Lor, Wanasalam, Randegan Wetan, dan Randegan Kulon.

\section{DAFTAR PUSTAKA}

[1] K. Perindustrian, Penyusunan Masterplan Wilayah Pusat Pertumbuhan Industri (WPPI) Di Jawa Barat. Jawa Barat: KEMENPERIN, 2015.

[2] B. P. S. P. J. Barat, Jawa Barat dalam Angka 2017. Jawa Barat: BPS, 2017.

[3] B. P. S. K. Majalengka, Kabupaten Majalengka dalam Angka 2017. Majalengka: BPS, 2017.

[4] P. dan P. D. K. M. Badan Perencanaan Pembangunan, Rencana Pembangunan Jangka Menengah Daerah Kabupaten Majalengka 2014-2018. Majalengka: Pemkab Majalengka, 2014.

[5] M. W. Kumalasari, "Faktor-Faktor Yang Berpengaruh Terhadap Pemilihan Lokasi Industri Manufaktur Skala Besar dan Sedang," Universitas Sebelas Maret, 2012.

[6] A. D. Febriyanti, "Penentuan Lokasi Industri di Kompleks SIER Surabaya," 2012. [Online]. Available: https://www.kompasiana.com/a.ditafebriyanti/ implikasi-teorilokasi-terhadap-penentuan-lokasi-industri-di-kompleks-siersurabaya_55102f3e813311d438bc628a.

[7] S. Y. Sorensen, EU Textiles and Clothing Sector: Location Decisions. Dublin: EMCC, 2008.

[8] Peraturan Menteri Perindustrian No. 35 tahun 2010 tentang Pedoman Teknis Kawasan Industri. 2010.

[9] N. dan D. W. Milevska, Delphi Analysis. Pittsburgh: University of Pittsburgh, 2010.

[10] R. S. Syaputra, "Penentuan Lokasi Bandar Udara di Kabupaten Lamongan," ITS, 2015.

[11] E. B. dkk Santoso, "Diktat Analisis Lokasi Dan Keruangan," ITS, 2012. 